\title{
Accounting, Taxation, and Auditing Issues Following the Legalization of Recreational Marijuana in Canada: Learning from the American Experience
}

\author{
Pauline Downer \\ Memorial University of Newfoundland \\ Tom Cooper \\ Memorial University of Newfoundland \\ Alex Faseruk \\ Memorial University of Newfoundland
}

Within North American there are several anomalous situations concerning the legality of marijuana either as a medical (legal across Canada but only 23 states) or recreational substance (not currently legal in Canada: legal in eight states and the District of Columbia, however still banned nationally). These situations have led to differences in the business model employed, the recording of accounting transactions on either a cash or accrual basis, and the auditing of public corporations, which may be listed or want to list on stock exchanges. This paper identifies the salient issues and comments on future directions.

\section{INTRODUCTION}

Marijuana or as it is more commonly known by its street names of pot, weed or grass is produced from the plant cannabis sativa. Marijuana has been used both medically and recreationally for thousands of years as it is one of the oldest naturally occurring psychoactive substances. Laws restricting the use of drugs were introduced early in the twentieth century in both Canada and the United Sates. In Canada, the control of illicit drugs began with the Opium Act of 1908 designed against Asian immigrants in British Columbia. It was quickly followed by the Proprietary and Patent Medicine Act, which prohibited the use of cocaine and required labelling of medicines if heroin, morphine or opium were ingredients. The 1908 acts created a black market for opium, and Parliament passed the Opium and Drugs Act which created harsh terms for drug offenders and expanded the list to include morphine and cocaine; marijuana was added in 1923. During World War One, the provinces added prohibition against some alcoholic beverages. Prohibition of alcohol was repealed by 1929 in all provinces, except Prince Edward Island which retained it until the end of the Second World War. It is worthy of note that drug enforcement in Canada at the time was treated as a criminal act without any rehabilitation programs and three-quarters of those convicted under the various acts were Chinese, (Dias 2003, 10-11). 
Over the years, the attitude toward drug usage in Canada has changed considerably. Although it is still illegal to grow, use and possess marijuana in most countries, including Canada, for medicinal purposes the Supreme Court of Canada declared its use as a potential therapy to be legal on July 30, 2001. In November 2015 during the 2015 federal election in Canada, the Leader of the Liberal Party, Justin Trudeau, declared that if elected his government would legalize the recreational use of marijuana. Provinces would provide legislation surrounding the licensure of the distribution of marijuana as a controlled substance in much the same way as alcohol is sold and distributed. The sharing of tax revenues would be a joint responsibility between the federal and provincial governments, given that both these jurisdictions have powers of taxation. Justin Trudeau's Liberal Party won the election and the legislation to allow recreational marijuana in Canada will come into force on July 1, 2018.

Much of what Canada is proposing to do is not being done in a vacuum as several states in the United States already permit the recreational use of marijuana and have enacted regulations and laws surrounding its usage. The current study examines what has transpired in the United States to identify various practices that can be adopted into the Canadian context. While there is limited discussion of the legal and moral issues associated with marijuana, the majority of the discussion centers around the accounting, taxation, and auditing issues, which are necessary to bring recreational marijuana as a legalized commodity to fruition on the anticipated date of July 1, 2018. This paper builds on the base that Canada already has publicly traded firms that engage in the medical marijuana business and also examines the business practices which have arisen in several states to comment on them to examine various models for Canada. This, the paper is divided into six sections. The first section provided an introduction. The second section reviews the legal and moral issues while the third outlines production and accounting issues. The fourth and fifth sections examine the various issues surrounding taxation and auditing, respectively. The sixth section concludes the paper.

\section{LEGAL AND MORAL ISSUES}

Despite almost a century of prohibition of marijuana, $43 \%$ of Canadians claim to have used it during their lifetime, and it is the most widely used illicit substance in Canada (Hajizadeh 2016, p. 453). Largely due to the ineffectiveness of the current system of prohibition, this issue has generated significant media and political attention. Simply decriminalizing marijuana would mean that the personal use would still be illegal for personal use, which could lead to a small fine, but would no longer treated as a criminal offense. Trafficking and importation would still be treated as criminal offenses. Legalization, however, would mean that marijuana would be legally available to those who had attained the age of majority for consumption of the substance. Legalization, as already done for other controlled substances, including alcohol, tobacco and fireworks, would allow government to regulate the sale, taxation, distribution and use of marijuana. However, there are still issues which have to be addressed with respect to the possibility of overdoses, risk of tragic intoxicated behavior (e.g. driving under the influence, operation of heavy equipment, and solicitation/engaging in prostitution), and dependency or addiction. However, many of these issues were and still are prevalent for alcohol following the lifting of its prohibition.

While Canada will be the first developed country to legalize marijuana, this process is not without roadblocks. Canada is part of three international conventions that need to be addressed as legalization takes place: the Convention on Psychotropic Substances of 1971; the Single Convention on Narcotic Drugs of 1961 (as amended by the 1972 Protocol); and the United Nations Convention against Illicit Traffic in Narcotic Drugs and Psychotropic Substances of 1988. Adhering to international protocols will be very problematic (Hajizadeh, 2016). Canadians travelling within Canada are required to carry their prescriptions, when travelling, which has created significant problems at airport security. These problems would only be exacerbated at international border crossings, when the intended country has marijuana as an illegal substance and prescriptions are not recognized. Canadians are also acutely aware of negative international ramifications stemming from the 1998 Winter Olympics in Nagano, Japan when Ross

Rebagliati was initially stripped of his Gold Medal in Men's Snowboarding for testing positive for THC following completion of the event. The decision was overturned because marijuana was not at the time a 
banned substance. THC has since been recognized by the World Anti-Doping Agency as a banned substance during competition, although outside of competition it is not banned.

\section{PRODUCTION AND ACCOUNTING ISSUES}

The legalization of recreational marijuana and allowing its harvesting leads to a realignment of the value chain in the cultivation, processing and distribution of marijuana, all of which have accounting issues that must be addressed to provide adequate accounting systems to be used in taxation and auditing.

From an economic viewpoint, the cultivation and production of legalized marijuana could result in increased employment opportunities, particularly in the areas of growing and packaging marijuana in government-approved cultivation facilities. These facilities would need to be licensed and inspected to enforce the relevant legislation, which provides for more civil servants to be hired. The salaries of the civil servants would be met through licensing fees and excise or sales taxes on the commodity. The legalization could also generate additional employment opportunities for individuals to provide educational sessions and health promotion initiatives to promote the safe use of the drug, not unlike drink or drive responsibility from manufacturers of alcohol. Nonetheless, due to potential automation and economies of scale as these facilities would undoubtedly be larger than small clandestine grow ups, the legalization may reduce the overall employment. The number of legal jobs generated (e.g. growers, distributors, accountants) in large mechanized facilities with economies of scale would probably be fewer than illegal smaller grow-ops. The yield in larger facilities should be greater and better quality with control and cost accounting procedures.

From a societal viewpoint, the legalization of marijuana, as a positive externality, could substantially reduce government spending on the enforcement of marijuana laws and free up court time to be used for other criminal offenses. In 2013, Statistics Canada reported that there were 73,000 marijuana-related criminal offenses ( $67 \%$ of all drug offenses in Canada), which had increased $8 \%$ in the preceding 10 years from 2003-13. The current marijuana policy and legal framework is associated with government costs between $\$ 500$ million to $\$ 1$ billion annually. Hajizadeh (2016) in providing these statistics concludes that the legalization of marijuana could lead to substantial savings in drug-related incarceration costs in Canada. Goltz \& Bogdanov (2016) from the Osgoode Hall Law School of York University in their article examined whether Canada could learn from two American states, "Lessons from Washington and Colorado: The Potential Financial Gains of Recreational Marijuana to Canada."

With the legalization of both medical and recreational marijuana, there are significant accounting issues that must be addressed, as they would in any other business. These accounting procedures address not only the nature of the business, but also need to be used for correct taxation and auditing.

Many CPA firms have begun to advertise cannabis accounting services and in so doing are portraying themselves as qualified accountants with experience in the cannabis industry. Not surprisingly, the majority of the advertisements come from states that permit the sale of marijuana. Cornelius CPAs promotes themselves as one of the first public accounting firms to offer accounting services to the cannabis industry in Colorado, saying that they work with licensed medical and recreational marijuana dispensaries, cultivation facilities, infused production facilities and quality control testing labs. They further claim that they have pioneered an accounting model that they recommend for their clients and that they,"...also peform [sic] the following services for our cannabis clients:"

http://corneliuscpas.com/cannabis_accounting.php:

1. Maintain accounting records

2. Prepare weekly and monthly payroll

3. Prepare federal and state income tax filings

4. Prepare sales and excise tax filings

5. Recommend and assist in implementing legal business structure and formation

6. Conduct financial statement audits, reviews and compilation for owners, investors and banks

7. Perform forensic accounting examinations when fraud or theft is discovered

8. Prepare financial and accounting policy and procedures 
9. Prepare internal control evaluations for existing businesses to discover weaknesses

10. Provide financial consulting services for business owners for a variety of financial areas

Camico (n.d.) in its cautionary note, "Marijuana Business Clients: 'Smokin' Hot' Issues for CPAs" identified and outlined several issues that are to addressed for CPAs who may become involved in this emerging and potentially risky future area of business, which were: Banking Problems; Policy Issues; Risk Management Considerations; Is This a Client the Firm Would Like to Have?; Accountant-Client Privilege; Client Screening; Federal Income Tax Treatment for Marijuana Business Clients; and Accounting Treatment for Marijuana Businesses Clients. Conversely on the other side, Canna Recruiter (n.d.) in its advertisement outlined several opportunities for employment in the cannabis industry, "Marijuana Accounting Jobs: The Devil is in the Details," which dealt with such opportunities as: Cannabis and the Big Banks; Marijuana Accounting Jobs Today; Legal Risks; What are Marijuana Accounting Jobs?; Job Qualifications \& Prerequisites; Dispensary Manager; Best Cities for Marijuana Accounting Jobs (Denver, Colorado, Sacramento, California, Portland, Oregon); and, The Future of Marijuana Accounting Jobs.

Finkbenbinder (2016) in her article, "Cannafinance Accounting: The Necessary Evil for a Successful Cannabis Business," outlined what she considered to be the requisite conditions for successfully accounting in the marijuana business to be compliant with various laws and conventions by examining such topics as: How is Accounting for a Cannabis Business Any Different; Section 208E Compliance; Set up the Books for Cost Accounting; What Expenses Can Be Included as Direct Costs; and Consistency is the Key.

AICPA, the Colorado Society of Certified Public Accountants (COCPA) and the Washington Society of Certified Public Accountants (WSCPA) jointly issued a brief on July 24, 2015 and issued a revised brief on January 8, 2016, "An Issue Brief on State Marijuana Laws and the CPA Profession" in order to prepare CPAs to provide accounting services to marijuana firms.

While offering accounting services other entities such as The Henry Levy Group in its industry brief 8 Common Accounting Problems Cannabis Businesses Face (December 31, 2014) outlined these potentially extensive problems:

Problem \#1: Not Knowing About the Cannabis Industry, State Laws, and Tax Law

Problem \#2: The (Near) Impossibility of Getting a Bank Account

Problem \#3: Not Keeping Track of Your Accounts

Problem \#4: The Living Nightmare Also Known as Being Audited

Problem \#5: Not Understanding Crucial Business Software

Problem \#6: Not Being Familiar With Cannabis-Friendly Business Merchants

Problem \#7: Needing to Safeguard Your Inventory Assets

Problem \#8: Not Knowing Any Relevant Business Consultants

One of the most pressing issues is adherence to IRS Section 208E of the tax code which prohibits deduction of expenses in a marijuana business unless they relate to the cost of goods sold Schroyer (2017). In this article entitled "Industry snapshot: Accounting Services for Marijuana Businesses-Data, trends and challenges", in Marijuana Business Magazine, he portrayed five warning signs (in the shape of traffic signs such as a stop sign) on the front page of the article and discussed tax on each subsequent page.

Coren $(2016,3)$ contends "The pot industry is desperate for good accounting software" wherein he reports that there were 727 companies dealing in cannabis with the investment totaling $\$ 1.2$ billion. An additional $\$ 20$ million investment is made each quarter. Legal sales of marijuana topped $\$ 4$ billion in 2016. The top five segments of the 17 reported in the market attracting these investments are: 1 . business software; 2 . media outlets and social networks; 3 . dispensaries and retailers; 4. edible products; and 5. oilbased products, while the bottom issues (13 through 17) are: 13. drug testing services; 14. IP-holding groups; 15. general medical marijuana; 16. lab testing; and 17. rehabilitation programs. Similarly, Tax Audit Pros as Certified Public Accountants (CPAs) in an online brief outlined similar issues on how to function effectively as marijuana accountants and touched on most of the same issues (Tax Audit ProsCertified Public Accountants (CPAs), 2017). Cannacomply (2017) outlined the issues which were 
necessary to set up an accounting system for the cannabis industry, while marketing accounting software and demonstrating how to be compliant with various conventions to be successful in an audit situation. They content it is not a matter if one would be audited but when.

Notwithstanding that there are various concerns about the accounting issues surrounding marijuana, Stevens (2015) in "A Cannabis Niche for Accountants? Working with Businesses that Grow and Sell Marijuana" points out that cannabis is a booming business ripe with opportunities for an accounting practice to work, and consult, with businesses in the marketplace on a full range of tax, sales tax, accounting, audit and workflow issues. At the time of the article in 2015, he pointed out that 23 states and the District of Columbia allowed marijuana for medical use and that four states at the time had allowed it recreationally (Alaska, Colorado, Oregon and Washington), but that seemed only to be the beginning and that marijuana sales by 2019 could reach $\$ 10.8$ billion (Stevens, 2015). Consider that at the time of the General Election on November 8, 2016, Arizona, California, Maine, Massachusetts, and Nevada all voted to legalize recreational marijuana for adults older than 21, while four more states Arkansas, Florida, Montana and North Dakota voted to ease access to medical marijuana (Coren 2016). There, however, still exists one major risk for marijuana businesses as the Drug Enforcement Agency still classifies marijuana as a Schedule 1 drug with, "no currently accepted medical use and a high potential for abuse" (Coren 2016, 4).

In order for marijuana to become a fully legal commodity, it must have very specific rules regarding the accounting rules to be enforced. Without the aid of direct pronouncements on the subject, many accounting firms would currently be in uncharted territory, especially in Canada. Consider the article by Freeman (2017) in the Financial Post, the leading daily business newspaper in Canada, carrying the title, "Biological assets': Accounting rules are adding haze to marijuana company financials." She points out that there is the potential for confusion, especially for the retail investor, which has resulted in calling on marijuana companies to take it on themselves to be more transparent. She further contends that publiclytraded cannabis companies are not exactly sure what to make of it either. She demonstrates that the current accounting procedures for the 'biological asset' rule may lead to misstatement of income as it prebooks income for crops as they are growing. Specifically, the biological asset rule credits the value of product that is growing at fair value minus selling costs and reports that figure on the income statement. Therefore, a company can report net income in a quarter during which they grew or harvested marijuana, but did not have any actual sales. Freeman (2017) contends that these rules are actually creating an accounting burden on these companies as they have to spend time to value the crops and/or hire experts to do it. The potential for confusion, especially to the retail investor, is that booked income may not materialize which would result in a future loss. Accrual accounting in this instance may make more sense, unlike in many states where marijuana sales are on a cash only or mostly cash business.

Freeman (2017) cites three of the largest medical marijuana in Canada, Canopy Growth Corp., Aphria Inc, and Aurora Cannabis Inc., neglected to disclose the impact of biological assets in their press releases for their most recent quarters, although they elaborated on these impacts in their management discussion and analysis document, but still the effects could be large. In Canopy's most recent quarter, the unrealized gain on the changes in the fair value of the company's biological assets amounted to $\$ 18.2$ million, double its actual revenue of $\$ 9.8$ million, thereby overstating the value of their biological assets, because by being too liberal with assumptions could lead to future periods with non-matching inventory. Neither the auditors nor investors take kindly to these types of misstatements.

Aphria highlighted in its most recent MD\&A that biological assets were worth $\$ 533,402$, while the net effect of unrealized changes in the fair value of those assets amounted to $\$ 74,268$ in the quarter ended November 30, 2016. It explained that in order to determine the fair value of those assets requires management to make a number of estimates including the expected cost necessary to cultivate marijuana to the point of harvest, harvesting and selling costs, anticipated sales price, and expected yield for crop. Given the requirement of conservatism, it is better to understate rather than overstate (Freeman, 2017). However, systematic understating is frowned upon by the markets as well.

Aurora touched on the impact of biological assets in its discussion of gross margin through explaining that in the previous year's period that the company did not generate any revenue from sales owing to the 
fact that they had not started the distribution part of their business, but recorded changes on the fair market value of biological assets of $\$ 2.2$ million on the inventory that it had amassed. For this reason, the company recorded a net loss of $\$ 2.7$ million in the second quarter of 2017 , when it was selling product, but a $\$ 600,000$ gain in the previous year for the same quarter. This anomaly was addressed in the company's management discussion.

Needless to say, there are significant accounting issues that are endemic to the cannabis industry, which has potential to become exacerbated as more firms enter the industry or as existing firms expand to service the increased demand when recreational marijuana is legalized. The current accounting practices carry the risk of write-downs of inventory, if the price per gram (ounce) were to fall or if the inventory remains unsold for a significant time, which may detract investors from entering the market (Freeman 2017). Accordingly, the market may not have the liquidity that it should have with the results that mergers might take place. Mergers would restrict competition, the illegal market in marijuana would continue, and these legitimate companies may become the target of money laundering. What is needed is an enhanced industry-wide metric (possibly non-IFRS) that would better account for cultivation, processing, and distribution that would not front-load income. There is the potential for shrinkage, which can be legitimate, such as loss of moisture (although taxes are assessed on dry weight), which is experienced in many other agricultural commodities as recognized on future exchanges, or illegal, such as various pilferage activities. Lastly, the emphasis in this industry has centered on the active chemical ingredients within cannabis, namely THC and CBD, but there is also the potential for other products that can be produced from the marijuana plant, such as hemp rope, paper, jewelry, fashioned into various other products like baskets, or made into plastics.

\section{TAXATION ISSUES}

Perhaps the most appealing argument in favor of the legalization of marijuana would be the increased tax revenue that it would bring generate with the elimination of its prohibition. This would then mean another source of revenue through various taxes that could be applied, such as excise, sales and sumptuary or sin taxes. The aforementioned high rate of usage would translate into high demand for recreational marijuana and yield significant tax revenue. The tax revenue has already been witnessed in Colorado, where marijuana has been legal since January 1, 2014. The fiscal results from the first two years showed a great monetary influx with medical and recreational sales reaching $\$ 1$ billion in 2015, which generated $\$ 135$ million in sundry taxes and fees (Hajizadeh 2016). To ensure that positive externalities are derived alongside the economic boost, the tax revenues, aside from increases in general revenue, are used for Colorado's public school capital construction assistance fund and public programs, such as substance abuse and regulation of marijuana usage.

While tax revenues are expected to increase, there are ethical issues that need to be addressed in tax compliance and morality as was the thrust in Alm and Torgler (2012) in their work, "Do Ethics Matter? Tax Compliance and Morality." In their paper, they examine the economics of crime, they argue that the puzzle of tax compliance can be explained at least in part by recognizing the typically neglected role of ethics in individual behavior, that is, individuals do not always behave as the selfish, rational, selfinterested, individuals portrayed in the standard neoclassical paradigm, but are rather motivated by many other factors that have as their main foundation some aspects of ethics. While the subsequent discussion

follows the traditional neoclassical model, it is assumed that there strategies wherein compliance with taxation policies can be compromised by ethical considerations which may be accomplished through tax evasion as tax avoidance strategies in the marijuana business are limited by existing tax codes, which define income by specifying deductions and limiting the scope of business, shown in this and subsequent sections.

In basic taxation, there are two items which must be considered, the tax base and the tax rate. In the transition from medical marijuana to recreational marijuana, it must be realized that there are different tax bases, given that there are different cannabinoids (active chemical ingredients produced by the cannabis plant), that are relevant for each type of marijuana. Actually, more than 100 different cannabinoids have 
been identified, but research has focused on only two of them so far: delta-9-tetrahydrocannabinol (THC) and cannabinol (CBD). THC is the substance known to cause the psychoactive effects or the high (stoned) associated from cannabis. THC has been shown to be effective in Post-Traumatic Stress Disorder (PTSD), functions as an appetite stimulant for HIV/AIDS patients, reduces nausea and vomiting from cancer treatment, helps patients with insomnia, inflammation, and pain (CanniMed, n.d.).

Conversely, CBD lacks the psychoactive effect of THC and has been shown to aid with epilepsy (including children with Dravet's Syndrome), some genetic brain disorders, Crohn's disease, ulcerative colitis, and Parkinson's disease. CBD helps make the high caused by THC more manageable and can reduce the likelihood of patients experiencing paranoia or anxiety caused by THC (CanniMed, n.d.).

Given that THC and CBD are intended for different purposes and different markets, what should be the relevant tax base, given that trichomes that grow on the outside of the marijuana flowers contain both THC and CBD? And, should high concentrations in either be a different tax base? Given the preponderance of CBD for legitimate medical purposes, should CBD be taxed at all, given the necessity of the drug and its intended usage? However, as medical marijuana would require a prescription, would physicians be writing prescriptions for people who could fake symptoms or would the physicians collude in the process? Could patients with legitimate, but fairly mild, conditions sell excess or unused marijuana for illicit use?

The basic question of why tax marijuana at all was posed by Philips (2015) in his brief, "Issues with Taxing Marijuana at the State Level." The most compelling argument is that the sale of marijuana should be subject to sales tax given that 45 states levy a general sales tax. So it would be equitable to treat it as any other good being sold. An interesting conundrum arises from the fact that 20 states require illegal marijuana sellers to purchase and place tax stamps on their marijuana, but virtually no one buys the stamps, since selling marijuana is illegal even with the stamps attached (Philips 2015). He also suggests that medical marijuana be subject to taxation since, at the current time, it is still best classified as a nonprescription drug owing to the lack of approval by the FDA. In designing a tax system for recreational marijuana, he identified several issues which would need to be taken into account, such as per-unit taxation, value-based taxation, tax rates over time and the earmarking of marijuana tax revenue.

Per-unit taxation is usually how excise taxes are applied, such as a per-unit amount on a package of cigarettes at both the federal and state levels. The advantage to this system would be that revenue would be fairly stable, particularly if the selling prices were to fluctuate. Taxing marijuana per weight may incentivize producers to cultivate marijuana with higher THC levels because it would fetch higher prices than lower THC marijuana, yet still be subject to the same per-unit tax. Accordingly, the tax might be more effectively applied to the intoxicating component rather than simple weight, not unlike the higher taxes placed on liquor and wine, due to the higher alcohol content over beer. However, the technology for measuring THC is not sufficiently reliable to implement this sort of system (Philips 2015).

Taxing the value chain might also be a plausible method of taxation to be used. Washington applies a $25 \%$ tax on the sale of marijuana from producers to processors on the sale of marijuana from producers to retailers, and again on retail sales (all on top of the applicable sales and gross receipt taxes). Colorado levies a $15 \%$ excise tax on the sale from producer to the retailer and another $10 \%$ excise tax on the final sales price, in addition to state sales and local taxes on the purchase of retail marijuana. The major advantages of these value-based taxes is that the tax will automatically adjust to the consumption base, and they will capture additional tax revenues from higher potency THC which will be reflected in the higher sales price without doing extensive testing. One problem is that these taxes might not be reflected in highly vertically integrated firms. Moreover the tax system could conceivably provide an incentive to become even more vertically integrated. Once the vertical integration is accomplished firms might then carry out horizontal integration, which may lessen competition and lead to higher prices, if oligopolies were to arise.

The question of how many taxes and fees are being paid on the tax base of marijuana is an important consideration and is dependent on the jurisdiction under consideration. Wolter (2017) in examining "Sales and Use Taxes on Weed," in California identified cannabis as retail sales of tangible personal property being subject to tax, unless the law provides a specific exemption. 
California law defines tangible personal property as an item that can be seen, weighed, measured, felt or touched. Cannabis and cannabis products are generally considered tangible personal property and without a specific exemption, sales of such property are subject to sales and use tax. A use tax may be due when one purchases taxable items without payment of California tax from an out-of-state vendor for use in California. A business may owe tax on items removed from inventory and used in California if taxes were not levied at the point of purchase. Effective January 1, 2018, a 15\% excise tax is to be imposed on cannabis and cannabis products. The $15 \%$ excise tax is calculated based on the average market price of the retail sale payable to the California Department of Tax and Fee Administration (CDTFA). In addition, a tax on the cultivation of cannabis will be imposed on cultivators at a rate of: $\$ 9.25$ per dry-weight ounce of cannabis flowers that enter the commercial market, and; $\$ 2.75$ per dry-weight ounce of cannabis leaves that enter the commercial market. On January 1, 2020, the cultivation tax will be subject to annual inflation adjustments.

In addition to paying these taxes, the business must also obtain a Seller's Permit and Cannabis Tax Permit. Online registration for cannabis tax permits are available beginning in November 2017. The tax permits are necessary to electronically file quarterly returns due on the last day of the month following the end of the quarterly period. This tax return is separate from other accounts that the business may have with the CDTFA. Cash payments are allowed only after applying for an exemption requesting departure from the No Cash policy. An exemption is only granted by filing a form showing undue hardship to document the nature of the business and why it is not possible to pay with a cashier's check or money order.

While the discussion has focused on taxes imposed by states, the federal government passed the Marihuana Tax Act of 1937 which was an excise tax levied on the hemp industry for not only rope, but as a cheaper source of paper. This act was overturned in 1969 in Leary v. United States and was repealed by Congress in 1970. Now the concern is more about the IRS taxing marijuana-based businesses and ensuring that corporate income tax is forthcoming from these businesses even by conservatives who generally favor States Rights as outlined by Reilly (2017) in "Tax Woes of the Marijuana Business Where Conservatives Lose their Enthusiasm for States Rights." Many states including California, Colorado, Nevada and Oregon have extensive briefs outlining and explaining their tax policies and revenue from marijuana sales.

Closely related to the issue of the tax base is the tax rate that would be imposed. Notwithstanding the various problems that the legalization of marijuana would make, marijuana is the second most consumed substance in Canada, behind only that of alcohol. The Canadian Imperial Bank of Commerce (CIBC) World Markets, as reported by Hajizadeh (2016), has estimated that the legalization of marijuana could create a $\$ 10$ billion annual national industry. They further advocate that the Canadian government could collect $50 \%$ or more of the potential $\$ 10$ billion if there is a high sumptuary tax (a tax levied on good such as alcohol and tobacco which are regarded as harmful to society or the consumption is limited in the best interest of society). However, high tax might not eliminate the black market, thereby not yielding the desired results to legalization. This issue was of particular concern by regulators in Colorado and Washington as they realized by setting the tax rate that it might in fact be too high realizing that legal recreational marijuana would still face competition from illegal sources where the prices in legal markets were higher than illegal markets. This situation creates a strong disincentive against consumers shifting purchases to the legalized market, particularly since many marijuana consumers may well have grown accustomed to shopping in the illegal market, when it was the only option available (Phillips 2015). Although it would be difficult to measure, studies on repeat purchases, brand loyalty, and relationship marketing may well explain some of the continuing presence of the black market in addition to the lower prices charged in that market segment. Phillips (2015) suggests that one approach that could be used to curb the black market is to phase-in the implementation of marijuana taxes gradually as the markets get fully up and running, citing that this approach is what federal regulators did when alcohol prohibition ended in the 1930s. Smalley (2017) contends that the taxation of marijuana is in a state of flux and that changes require that one needs to be mindful of regulatory changes, particularly as they relate to Section 208E, in his article, "Big Tax Changes Could Be Coming for the Cannabis Industry." 
Some of the issues that have been identified with respect to taxation are:

The Oregon Cannabis Institute https://oregoncannabisinstitute.com/accounting-bookkeeping outlines five common misconceptions surrounding taxation related issues:

Misconception 1: Marijuana dispensaries are not federally approved, so they are not subject to income taxes.

Misconception 2: Marijuana businesses are filled [sic] under 501(c) nonprofit tax code.

Misconception 3: It's best to keep operating records in this industry.

Misconception 4: Medical marijuana dispensaries are cash based businesses. How is the IRS going to find out what I made, if I don't claim my income?

Misconception 5: Collecting donations in return for marijuana.

During the 2015 General Election in Canada, the then leader of the Liberal Party and now Prime Minister of Canada promised the legalization of recreational marijuana in Canada to go along with the already existing medical marijuana. On June 30, 2016, the Minister of Justice and Attorney General of Canada, the Minister of Public Safety and Emergency Preparedness and the Minister of Health announced the creation of a nine-member Task Force on Cannabis Legalization and Regulation. Its mandate was to consult and provide advice to the federal government on the design of a new legislative and regulatory framework for legal access to cannabis following the commitment to "legalize, regulate, and restrict access,' as announced in its December 2015 Speech from the Throne. The final report, "A Framework for the Legalization and Regulation of Cannabis in Canada" was released on November 30, 2016. To fulfil its mandate, the Task Force consulted with provincial, territorial and municipal governments, patients, advocates, indigenous governments and representative organizations, employers and a wide spectrum of other industry stakeholders. The Task Force received 30,000 submissions from both individuals and organizations in Canada, and looked beyond Canada's boarders to learn from jurisdictions that have allowed cannabis for recreational purposes, such as Colorado, Washington and Uruguay (Lexology 2017).

The Task Force set out guiding principles and values to make its recommendations. These were: protection of public health and safety; compassion for vulnerable members of society and patients; fairness in avoiding disproportionate or unjustified burdens to particular groups or members of society; collaboration at all levels of government and members of the international community; commitment to evidence-informed policy, research and information exchange; and flexibility in implementing the new framework (Lexology 2017).

While Prime Minister Trudeau stated that tax revenue was not one of the principal reasons for legalization, it is nonetheless an important consideration. Lexology (2017) states that there are four key takeaways from the Task Force relating to taxation.

\section{Taxation and Pricing Objectives}

The report specified that taxation and pricing policy decisions involve a tradeoff between the government's desire to discourage consumption and reduce black market profits, which would be accomplished through:

- fixing of prices - a price set for each cannabis product;

- setting minimum/maximum prices - a range of prices that can be charged for each cannabis product;

- per unit taxes - a tax on each specific quantity or product sold;

- sales taxes - a percentage tax on the dollar value of every sale; and

- limits on production amounts - a limit on the amount of product produced and sold to control price through market supply.

The amount of regulation in Canada for recreational marijuana seems to be greater than in jurisdictions in the United States, particularly with price fixing and controlling supply, as well as taxation. These requirements are not unlike the Blue Laws that were enacted following the end of prohibition for alcohol and reflect how various provinces still control the licensing, manufacture, supply and pricing of alcohol through government agencies in several provinces. 


\section{Use of Tax Revenues}

While the primary reason for the legalization of marijuana may not have been to enhance tax revenue, the government has indicated that these revenues should be used to fund cannabis-related programs and services, such as addiction treatment, mental health support and education programs. However, the scope of these programs need to be better defined as to identify what will qualify for expenditures and grants.

\section{Medical vs. Non-Medical Taxation}

Currently, medical cannabis purchased through a licensed producer under the Access to Cannabis for Medical Purposes Regulations is subject to a 5\% Goods and Services Tax (GST) at the federal level, as well as any other applicable provincial sales tax. Medical marijuana does not benefit from the excise tax exemption under the Excise Tax Act as other prescription drugs do. Accordingly, the Task Force has recommended that medical cannabis patients pay the same level of tax as non-medical consumers.

\section{Potential Patient Implications}

As outlined in the preceding section, the single tax policy may be detrimental to patients who rely on medical marijuana, while sharing the tax burden with recreational users. If there were a tax break, recreational users may access the medical stream fraudulently to obtain it at lower prices. This process may make it easier for physicians, who may already be reluctant to prescribe medical cannabis, to refuse to prescribe medical marijuana and simply refer patients to the non-medical stream instead, which would make it harder for medical patients to access certain ancillary benefits tied to medical cannabis, such as tax deductibility, potential insurance coverage and employer accommodation related to appropriate medical use in the workplace (Lexology 2010).

\section{Setting a Tax Rate on Marijuana in Canada}

On October 3, 2017, at a meeting of the First Minister's Meeting in Ottawa, Prime Minister Trudeau unilaterally announced to the Premiers that the federal government wants to impose a $10 \%$ federal tax on recreational cannabis. Specifically the federal government would impose a dollar-a-gram excise tax up to prices of $\$ 10$. On cannabis priced at higher than $\$ 10-\mathrm{a}-$ gram, the tax would be a flat tax of $10 \%$. $\mathrm{He}$ further said that the proposal would include a plan to split the tax revenue 50-50 with the provinces (Siebert 2017). The business press and the markets reacted well to the announcement. The shares of Canopy (WEED.TO) increased $2.7 \%$ on the announcement and Aphria (APH.TO) rose $1.0 \%$ (Vandelle 2017). The other levels of government were, however, not as positive with the news.

Vic Neufeld, CEO of Aphria, in speaking in favor of the proposed tax system, said that it was fair, equitable and takes aim at the black market for cannabis, while making it abundantly clear that keeping costs low will be a critical factor for the entire supply chain (Morningstar 2017). The Cannabis Compliance Institute (2017) for medical marijuana had previously stated that quality assurance in every step of the process is also key to a competitive advantage. Engel (2016) argued that appropriate planning will also help the transition in Canada from the medical marijuana to the recreational market citing that Canada already has one of the most advanced medical cannabis industries in the world, which will help build a new regulatory framework for recreational marijuana.

The Canadian Minister of Finance, Bill Morneau, had already stated in June 2017 that the federal government wanted to keep marijuana taxes low after legalization to help drive criminals and black market dealers out of business (Chartrand 2017). While the announcement was not unanticipated, many of the provinces quickly objected including Quebec, Manitoba and British Columbia arguing that the 50-50 formula is unacceptable, as provinces would bear most of the costs [Authier (2017), Robertson (2017].

In a further discussion on the issue, Matthew Trudeau (no declared relation to the Prime Minister) examined American tax rates for the District of Columbia and eight states that allow recreational marijuana (Alaska, California, Colorado, Maine, Massachusetts, Nevada, Oregon and Washington) to examine their tax policies. Many of these issues have already been identified already in the current study. As usual Canadian tax policy will be set in Canada but may incorporate some elements of the American experience. Unless marijuana is incorporated into a revised North American Free Trade Agreement 
(NAFTA), these markets will remain separate and laws about importing across national borders will remain in effect.

\section{AUDITING ISSUES}

Auditing for the purpose of becoming a fully reporting public company will become an important issue as companies wish to raise capital and trade on stock exchanges as was outlined by Market Wire in its article of December 27, 2016 (Market Wired, 2016) entitled, "Marijuana Company of America has Engaged Auditing Firm to Prepare for Move to Fully Reporting Public Company." The Marijuana Company of America Inc. (OTC PINK: MOCA), an innovative cannabis and hemp marketing company engaged L\&L CPAs PA as its independent audit firm to complete a two-year audit as part of the process to become a fully reporting public company with the intent of moving from the OTC to a listed exchange. In so doing, the engaged auditors are working with MOCA's legal counsel to complete the necessary procedures to file a registration statement with the Security and Exchange Commission (SEC) in order to enhance their long-term shareholder value, while attracting a broader and more diverse shareholder base. In the words of MOCA's CEO, Donald Steinberg, "Our goal is to be a fully transparent reporting company. As we grow and take these major steps, we want our shareholders to be well-informed about our plans and our progress. By becoming a fully-reporting, transparent public company, we may be better positioned to enhance stock liquidity and attract institutional investors, which will fundamentally enhance the value of our Company."

Nothing which was said in the CEO's preceding statement would be considered out of line with any other public company that was trading in the OTC market and wanted to then trade on a listed exchange through interfacing with the auditors and the legal teams. However, given the newness of this movement in the cannabis industry, it was very noteworthy. Steinberg (Market Wired, 2016) said, "Our goal is to be fully reporting on the most reputable exchange we qualify for, so our shareholders have all the information they need to follow our progress in detail." L\&L CPAs, PA is registered with the PCAOB and is experienced in conducting audits of public companies in the cannabis industry. Completing this audit will help to ensure the accuracy and completeness of MCOA's financial information, as well as to identify and perhaps strengthen its internal controls over financial reporting.

In estimating what the revenue from marijuana sales could be, Phillips (2015) outlined several factors that could negatively impact marijuana revenue as: federal intervention (most likely in the form of federal prosecutions against a controlled substance); legalization's effect on marijuana prices; tax evasion (the specter of Al Capone could haunt this market); treatment of homegrown marijuana (i.e., the ability of individuals to grow their own marijuana on a small scale as Alaska, Colorado and the District of Columbia each allow individuals to grow up to six plants per person for non-medical purposes, Oregon four. Personal cultivation is not allowed in Washington); and the substitution of marijuana for alcohol. Philips (2015) also outlined factors that could positively impact marijuana revenue as: legalization's effect on marijuana consumption (which is expected to increase); marijuana tourism; and legalization's impact on income tax revenues. One area that he did not consider was the potential for sales of marijuana seeds for personal consumption or even the cultivation facilities which may want to improve the strains of marijuana or broaden the market through different types. Of course, distribution could be a problem as marijuana would not be allowed to be shipped by mail, for example.

While there are many auditing issues for publicly traded marijuana firms, in many ways this is just the tip of the iceberg as compliance auditing for state (provincial) regulators and the IRS (Canada Revenue Agency) will become widespread as more businesses enter this potentially lucrative market. Consider Schiller (2017) of the Cannabis Business Times in her article "New Compliance Tool Designed to Simplify Auditing" with the sub-title "Simplifya's CTO shares how cultivators can use the software to increase compliance through self-audits and better prepare for state inspections." Similarly, Cannabis Compliance Audits were shown to have benefits by the Denver Consulting Group (n.d.) (self-proclaimed as Colorado's Cannabis Experts) to provide assurance to banks and bankers, investors, landlords, realtors, government officials and bodies, licensees, insurance companies in providing various types of cannabis 
compliance audits (Retail Marijuana Center (recreational store), Medical Marijuana Center (medical store), Retail Marijuana Cultivation Facility (recreational grow), Optional Premises Cultivation (medical grow), Retail Marijuana Product Manufacturing Facility (recreational kitchen/concentrate processor) and Marijuana Infused Product Manufacturer (medical kitchen/concentrate processor) with the benefits from a compliance audit of providing (Objective $3^{\text {rd }}$ Party Assessment of Compliance; Thorough, Quantitative, and Applicable Reports; Create a Culture of Compliance; Proof of Due Diligence; Establish a History of Compliance; Peace of Mind). There advertisement ends with the advice, "Schedule your cannabis compliance audit today."

Notwithstanding the desire by auditing firms to provide auditing services to be compliant with accounting rules and regulations, there is still the stigma which goes with the cannabis business. For example, the Internet carries such articles as, Migoya (2017) "DOJ is secretly using IRS to investigate Colorado pot shops in guise of audits, lawsuit says" but it also carries the denial from the IRS as it says, "IRS says it just wants to determine what shop owes in taxes." Daniels (2016) in "IRS said to be auditing Colorado marijuana businesses" and Yakowicz (2016) in "Why the IRS Is 'Aggressively' Auditing a Bunch of Colorado Cannabis Companies" had already made similar points regarding the then anticipated audits. Oregon may well be next Alice of "I Love Growing Marijuana" (2017) writes "Attorney General and Cannabis Auditing is Coming to Oregon." Paying taxes in cash and auditing a cash-only business may be a problem as outlined by Dillow (2017), "Paying taxes in cash, marijuana companies have a lot to hash out with IRS" and Arrowsmith (2017) "IRS goes green: Hashing out payments from the marijuana industry." Wells (2014) had written that at that time the IRS would be concerned more with the collection of taxes than with prosecution in her article, "Accountants exhale after IRS takes stand on pot." However, what is disconcerting is that the attitude and rules change and evolve over time. The California Cannabis CPA (n.d.) in the article "Lowering the Risk of an IRS Audit for your Marijuana Business" provides the rather cogent observation that every cannabis company has a substantially higher risk of being audited with the best practices to reduce the chance of being audited with three rules: 1. Maintain Careful Records and Copies; 2. Make Sure to File on Time; and 3. Comply with All State Laws. Throughout the discussion there is the implicit assumption that the business is using the services of a CPA.

\section{CONCLUSION}

In terms of the product life cycle as a legitimate business enterprise, the cannabis business is still in its infancy for both the medical and recreational segments of the market, as business practices including the cultivation and distribution of marijuana continue to evolve, particularly as cannabis is still an illegal substance in most jurisdictions. Given this current state, the legal, accounting, taxation and auditing practices also continue to evolve.

Proponents of treating cannabis as a biological asset contend that it is the most relevant measurement of biological transformation. If cannabis is indeed a biological asset, the main issue that has to be resolved in Canada, is how the fair value of that asset is determined. While determining the fair value requires examining the sale of the product in an active market, defining what that actual active market is may result in different assumptions by parties engaged in the production of cannabis. One of the most important qualitative characteristics of financial information is relevance and reliability. Often the two are in conflict. If a consensus is not reached on the valuation of the cannabis, how reliable or relevant will the financial information be to investors who rely on financial statements? Is the value of the cannabis based on ultimate sale price, is the strength of the product (specifically THC) a determinant of value; is value affected by the distribution and promotion method? The cost, the complexity, and the practical difficulties of the fair value requirement all will have significant impact. The issues with the valuation do not end at the recording stage. How will Canada train the auditors in determining whether or not the valuation method used by management leads to the production of financial statements that are not materially misstated? The government, the firms, the accountants and the auditors are entering unchartered waters, which may also mean higher auditing invoices for companies which enter into this new business of legalized cannabis. 
While the Prime Minister of Canada has announced a plan that would see the provincial and the federal government coffers split a $10 \%$ excise tax, many questions remain unanswered. Who will administer this tax? It is assumed that this is a transaction tax similar to the current GST/HST in Canada which ranges from $5 \%$ to $15 \%$, is the introduction of this new $10 \%$ tax really necessary? Instead, perhaps using the current system would be easier and better understood by Canadians, rather than introducing an entirely new tax.

The transaction-based tax may be the easier problem to solve, but the actual taxation of the profits from a business that sells cannabis and is required to report income based on the fair value of the crop, is the more troublesome question. The Canadian government is currently attempting to change the way that small businesses are taxed, with tax rates expected to significantly increase. It is assumed that the taxation of profits from cannabis businesses will allow unrealized profit to be removed from the taxation base until it is recognized revenue. This, however, has not been clearly identified as the intended course of action. Given the uncertainty currently surrounding the taxation of business income in Canada, producers of cannabis face even higher degrees of ambiguity. The taxation of the ultimate profit for these businesses is an important question that needs a direct answer. Given that the current government has created chaos around their proposed vision for a fairer tax system, it is not expected that the means of taxing cannabis will become clearer any time soon, and as such will be clouded in haze.

\section{ACKNOWLEDGEMENTS}

The authors thank the participants at the 2018 MBAA-International North American Accounting Society conference for their valuable comments on an earlier version of this paper. Memorial University of Newfoundland's grant accounts (Downer no. 211811) provided financial support for this project. 


\section{REFERENCES}

AICPA. (issued July 24, 2015, updated January 8, 2016). An Issue Brief on State Marijuana Laws and the CPA Profession, AICPA in conjunction with the Colorado Society of Certified Public Accountants and the Washington Society of Certified Public Accountants.

AICPA. (n.d.), Providing Services to Businesses in the Marijuana Industry, https://www.aicpa.org/advocacy/state/pages/marijuana.aspx accessed on 10/13/2017

Alice of I Love Growing Marijuana. (2017). Attorney General [Jeff Sessions] and Cannabis Auditing is [sic] Coming to Oregon, I Love Growing Marijuana, September 20, 2017 http://www.ilovegrowingmarijuana.com/attorney-general-cannabis-auditing-coming-oregon accessed 10/13/2017

Alm, J., \& Torgler, B. (2012). Do Ethics Matter? Tax Compliance and Morality. Tulane Economics Working Paper Series, Working Paper 1207, Tulane University.

Arrowsmith, R. (2017). IRS goes green: Hashing out payments from the marijuana industry. Accounting Today,https://www.accountingtoday.com/opinion/irs-goes-green-hashing-out-payments-from-themarijuana-industry accessed on 10/13/2017

Authier, P. (2017). Quebec wants bigger chunk of federal marijuana excise tax. Montreal Gazette, http://montrealgazette.com/news/local-news/montreal-wants-in-on-marijuana-tax-coderrereminds-quebec-feds accessed on 10/05/2017

California Cannabis CPA. (2017). Lowering the Risk of an IRS Audit for your Marijuana Business, http://www.californiacannabiscpa.com/blog/lowering-the-risk-of-an-irs-audit-for-your-marijuanabusiness accessed on 10/13/2017

Camico. (n.d.), Marijuana Business Clients: 'Smokin' Hot' Issues for CPAs. http://www.camico.com/blog/Marijuana_Business_Clients_Smokin_Hot_Issues_for_CPAs accessed on 10/13/2017

Canna Recruiter. (2017). Marijuana Accounting Jobs: The Devil is in the Details. https://www.cannarecruiter.com/marijuana-accounting-jobs accessed on 10/13/2017

Cannabis Compliance Inc. (n.d.). Quality is Your Competitive Advantage. http://www.cannabiscomplianceinc.com/medical-cannabis/cultivation-and-sales-license/qualityassurance-audits accessed on 10/13/2017

Cannacomply. (n.d.), Accounting for the Cannabis Industry, http://cannacomply.net/accounting-services accessed on 10/13/2017

CNW Group. (2016). Canna Score Compliance Auditing for Cannabis-Related Businesses, Used by Banks and Financial Institutions, CNW Group. http://www.cscomply.com accessed on $10 / 13 / 2017$

Colorado-Department of Revenue. (n.d.). Marijuana Tax Data. https://www.colorado.gov/pacific/revenue/colorado-marijuana-tax-data accessed 10/05/2017

Coren, M. J. (2016). The pot industry is desperate for good accounting software, Quartz. https:/qz.com/842792/the-pot-industry-is-looking-awfully-boring accessed 10/13/2017

Cornelius CPA (n.d.), Cannabis Accounting Services, http://corneliuscpas.com/cannabis accounting.php accessed on $10 / 13 / 2017$

Daniels, J. (2016). IRS said to be auditing Colorado marijuana businesses, $C N B C$. https://www.cnbc.com/2016/07/2016/irs-said-to-be-auditing-colorado-marijuana-businesses.html accessed on $10 / 13 / 2017$

Denver Consulting Group. (n.d.). Cannabis Compliance Audits. http://denverconsultinggroup.com/how-to own-a-retail-marijuana-business/cannabis-compliance-audits accessed 10/13/2017

Dias, G. (2003). "Canada's Drug Laws: Prohibition is not the Answer" in Perspectives on Canadian Drug Policy: Volume 1. Kingston ON: The John Howard Society, 10-24.

Dollow, C. (2017). Paying taxes in cash, marijuana companies has a lot to hash out with IRS, CNBC https://www.cnbc.com/2017/04/18/marijuana-companies-sending-a-huge-cash-roll-to-irs-on-taxday.html accessed on 10/13/2017 
Engel, G. (2016). Planning for the future of cannabis in Canada, Policy Options.

http://policyoptions.irpp.org.magazines/june-2016/planning-for-the-future-of-cannabis-in-canada. accessed on 10/05/2017

Finkenbinder, C. (2016). Cannafinance Accounting: The Necessary Evil for a Successful Cannabis Business. Cannabiz Journal, (June 23, 2016). http://cannabizjournal-june2016.com accessed $10 / 05 / 2017$

Freeman, S. (2017). 'Biological assets': Accounting rules are adding haze to marijuana company financials, Financial Post. http://business.financialpost.com/commodities/agriculture/biologicalassets-accounting-rules-are-adding-haze-to-marijuana-company-financials accessed on 10/13/17

Goltz, N., \& Bogdanov, E. (2016). Lessons from Washington and Colorado: The Potential Financial Gains of Recreational Marijuana to Canada. Osgoode Legal Studies Research Paper Series, 118.

Hajizadeh, M. (2016). Legalizing and Regulating Marijuana in Canada: Review of Potential Economic, Social and Health Impacts. International Journal of Health Policy and Management, 5(8), 453-456.

Henry Levy Group. (2014). 8 Common Accounting Problems Cannabis Businesses Face. The Henry Levy Group: A CPA Firm. https://www.leafly.ca/news/industry/8-common-accounting-problemscannabis-businesses-face accessed 10/13/2017

Lexology. (2017). Task Force Report: Taxation and Pricing of Cannabis, Lexology (January 6, 2017). https://www.lexology.com/library/detail.aspx?g=6151dd9d-7688-414f-85ea-c0a04baf294a accessed 10/05/2017

Marijuana Accounting Firms. (n.d.). Featured Listings. https://www.ganjapreneur.com/business/california- cannabis-cpa accessed on 10/13/2017

Marijuana Laws Canada. (n.d.). Canada's Leading Marijuana Consultants. http://www.marijuanalaws.ca/taxes-CRA-court.html. accessed on 10/05/2017

Market Wired. (2017). Marijuana Company of America Has Engaged Auditing Firm to Prepare for Move to Fully Reporting Public Company. http://www.marketwired.com/press-release/marijuanacompany-america-hasengaged-auditing-firm-prepar-move-fully-reporting-public-2185472.htm accessed on $10 / 13 / 2017$

Migoya, D. (2017). DOJ is secretly using IRS to investigate Colorado pot shops in guise of audits, lawsuit says: IRS says it just wants to determine what shop owes in taxes. The Denver Post. http://www.denverpost.com/2017/09/01/lawsuit-doj-irs-investigate-colorado-pot-shops accessed $10 / 13 / 2017$

McKenna, B. (2017). Morneau wants provinces to keep taxes on legalized marijuana low. The Globe and Mail. https://beta.theglobeandmail.com/news/politics/canadian-financeministers-to-discussmarijuana-taxation-in-ottawa. accessed on 10/05/2017

Morningstar. (2017), New Proposed Federal Tax Plan for Cannabis Underscores Need for Low Cost Producers, Canada NewsWire http://news.morningstar.com/all/canada-newswire/20171005C7604. accessed on 10/05/2017

Nevada-Department of Taxation. (n.d.), Marijuana Regulations. https://tax.nv.gov/FAQs/Marijuana_Proposed_Temporary_Regulation_T002-17 accessed on $10 / 05 / 2017$

Oregon Cannabis Institute. (n.d.). Accounting \& Bookkeeping [sic] https://oregoncannabisinstitute.com/accounting-bookkeeping accessed on 10/13/2017

Philips, R. (2015). Issues with Taxing Marijuana at the State Level. The Institute on Taxation \& Economic Policy.

Reilly, P. J. (2017). Tax Woes of the Marijuana Business Where Conservatives Lose their Enthusiasm for States Rights, Forbes. https://www.forbes.com/sites/peterjreilly/2017/06/03/tax-woes-of-themarijuana-business-where-conservatives-lose-their-enthusiasm-for-states-rights accessed on $10 / 13 / 2017$

84 Journal of Accounting and Finance Vol. 18(6) 2018 
Robertson, D. (2017), Pallister balks at Trudeau's proposed 10 per cent tax on cannabis. Winnipeg Free Press, https://www.winnipegfreepress.com/local/pallister-balks-at-trudeaus-proposed-10-percent-tax-on-cannabis accessed on 10/05/2017

Schiller, M. (2017). New Compliance Tools Designed to Simplify Auditing: Simplifya's CTO shares how cultivators can use the software to increase compliance through self-audits and better prepare for state inspections. Cannabis Business Times.

http://www.cannabisbusinesstimes.com/article/simplifya-software-cannabis-state-audits. accessed on $10 / 13 / 2017$

Schroyer, J. (2017). Industry snapshot: Accounting Services for Marijuana Businesses-Data, trends and Challenges. Marijuana Business Magazine https://mjbizmagazine.com/industry-snapshotaccounting-services-for-marijuana-businesses accessed 10/13/2017

Siebert, A. (2017). Trudeau wants to impose a 10-percent federal tax on recreational cannabis. Georgia Straight Vancouver's News \&Entertainment Weekly. https:/www.straight.com/cannabis/976026/trudeau-wants-impose-10-percent-federal-taxrecreational-cannabis. accessed 10/05/2017

Smalley, C. (2017). Big Tax Changes Could Be Coming for the Cannabis Industry (April 12, 2017). https://www.accountingweb.com/tax/business-tax/big-tax-changes-could-be-coming-for-thecannabis-industry accessed on 10/05/2017

Tax Audit Pros-Certified Public Accountants. (CPAs) (2017). Marijuana Accountants for Cannabis Industry. http://taxauditpros.com. accessed 10/05/2017

Trudeau, M. (2017). Marijuana taxes in Canada. News Lift. http://news.lift.co/marijuana-taxes-canada accessed 10/05/2017

Vandelle, I. (2017). Trudeau avoided killing the golden goose with marijuana tax proposal: Analyst. BNN. http://www.bnn.ca/trudeau-avoided-killing-the-golden-goose-with-marijuana-tax-proposalanalyst-1.875243. accessed 10/05/2017

Webb, S. (2015). A Cannabis Niche for Accountants? Working with Businesses that Grow and Sell Marijuana, CPA Practice Advisor, http://www.cpapracticeadvisor.com/accounting-audit accessed on $10 / 13 / 2017$

Wells, J. (2014). Accountants exhale after IRS takes stand on pot. CNBC. https://www.cnbc.com/2014/11/20/accountants-exhale-after-irs-takes-stand-on-pot.html accessed on $10 / 13 / 2017$

Yakowicz, W. (2016). Why the IRS is 'Aggressively Auditing a Bunch of Colorado Cannabis Company. INC.com. https://www.inc.com/will-yakowicz/irs-aggressively-auditing-marijuanacompanies.html accessed on 10/13/2017

Wolter, R. J. (2017). Sales and Use Taxes on Weed. Nesteggg [sic] Accounting. http://www.nesteggg.com/news/sales-and-use-taxes-on-weed. accessed on 10/13/2017 